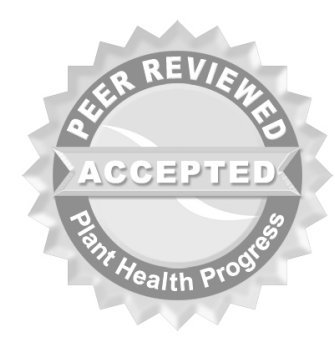

(C) 2011 Plant Management Network.

Accepted for publication 8 July 2011. Published 30 September 2011.

\title{
Impact of Crop Rotation and Bio-covers on Soybean Cyst Nematode
}

J ason P. Wight, Department of Plant Sciences, University of Tennessee, 2431 Joe Johnson Drive, Knoxville, TN 37996;

Fred L. Allen, Department of Soil and Crop Sciences, 2474 TAMU, College Station, TX 77845 (currently, Department of Plant Sciences, University of Tennessee, 2431 Joe Johnson Drive, Knoxville, TN 37996); Patricia A. Donald, USDA-ARS, 605 Airways Boulevard, Jackson, TN 38301; Don D. Tyler, Department of Bioengineering and Soil Science, University of Tennessee, West Tennessee Research and Education Center, 605 Airways Boulevard, Jackson, TN 38301; and Arnold M. Saxton, Department of Animal Science, University of Tennessee, 2505 River Drive, Knoxville, TN 37996

Corresponding author: Jason P. Wight. Jwight@ag.tamu.edu

Wight, J. P., Allen, F. L., Donald, P. A., Tyler, D. D., and Saxton, A. M. 2011. Impact of crop rotation and bio-covers on soybean cyst nematode. Online. Plant Health Progress doi:10.1094/PHP-2010-0930-04-RS.

\begin{abstract}
This research examined the effects of crop rotations and winter soil bio-covers on soybean cyst nematode (SCN) egg population density (EPD) under no-tillage. A field experiment with split-block treatments and four replications was conducted over three years with the whole-block treatments being rotations of corn (Zea mays L.), soybean [Glycine max (L.) Merr], and cotton (Gossypium hirsutum L.). Split-block treatments were bio-covers of winter wheat (Triticum aestivum L.), hairy vetch (Vicia villosa Roth), poultry litter, and fallow. Eggs were found in soybean-free sequences all four years, indicating potential residual viable SCN eggs in soil for seven years. Rotations with higher frequencies of soybean had significantly higher ( $\mathrm{P} \leq 0.01)$ SCN EPD than others, with continuous soybean being greatest. We did not observe a significant difference due to bio-cover on SCN EPD.
\end{abstract}

\section{I ntroduction}

Soybean cyst nematodes (SCN) can cause up to $30 \%$ yield loss with no visible above-ground symptoms (16). Crop rotation has proven to be an effective management practice for some nematode species. It has been shown that rotation with non-host or SCN-resistant soybean cultivars reduces SCN population density and increases soybean yield in western Tennessee (8). However, SCN eggs encapsulated within a cyst go dormant during cooler temperatures, allowing them to survive harsh winter conditions $(20,28)$. It has been observed that SCN eggs may survive up to 12 years in the absence of a host (1). Encysted eggs can remain viable in soil for more than three years in Mississippi with no host plant present (12), and over five years in Minnesota (18). Therefore, rotation designs should be tailored to site-specific conditions.

Winter covers, or bio-covers, reduce erosion and promote soil and water quality, and may affect nematode populations. Bio-covers that are alternative SCN host plants, such as hairy vetch (Viciavillosa Roth) (21), can increase nematode population density during winter (5). Non-host cover crops such as wheat (Triticum aestivum L.) can reduce SCN populations (12). Winter annuals present during winter fallow, including henbit (Lamium amplexicaule L.), chickweed (Stellaria media (L.) Vill.), and purple deadnettle (Lamium purpureum L.), can serve as SCN hosts (27). However, no indication of SCN reproduction was observed during three winter fallow periods on weeds or crimson clover (Trifolium incarnatum L.) in soybean production fields in western Tennessee (6). Poultry litter, used as a soil amendment, can suppress 
nematode communities by encouraging the growth of parasitic fungi, such Fusarium oxysporum (12).

The effects of tillage on SCN reproduction have been mixed. In general, notillage appears to reduce populations of $\operatorname{SCN}(2,10,25)$ but lack of effect also has been reported $(12,17)$. The objective of this study was to evaluate the effects of cropping sequence and winter bio-cover combinations on populations of SCN under no-tillage production.

\section{Site Description}

The field study was begun in 2002 at the Research and Education Center at Milan (RECM) in Milan, TN $\left(35.54^{\circ} \mathrm{N} 88.44^{\circ} \mathrm{W}\right)$. Mean annual precipitation is $135 \mathrm{~cm}$ and mean annual temperature is $16^{\circ} \mathrm{C}$. The soil type is a Loring B2 series: fine-silty, mixed, thermic Typic Fragiudalf.

The field site was planted in soybean in 1995 and 1996, cotton in 1997 and 1998 , and soybean in 1999. In 2000, the entire site was planted in corn, and left fallow during the growing season prior to the experiment in 2001. Wheat was planted during each winter. The field was under no-tillage production for over 16 years prior to initiation of this experiment.

\section{Experiment Design}

The experiment was a split-block design with treatments arranged in randomized complete blocks. The whole plot treatments were crop rotations, which were strip-applied across the length of the field. Thirteen individual cropping rotations consisting of glyphosate-resistant corn, soybean, and cotton were planted (Table 1). Four bio-cover treatments, including hairy vetch, winter wheat, poultry litter, and fallow, were strip-applied as a sub-plot treatment perpendicular to crop sequence strips to give 52 sequence $\times$ bio-cover combinations applied to separate $6.1-\mathrm{m}$ by $12.2-\mathrm{m}$ subplots. Each treatment combination was replicated four times for a total of 208 plots. Cultivars planted were 'PM 1218 BG/RR' cotton, 'DKC 6410 RR' corn, and 'USG 7440nRR' soybean, which has exhibited moderate resistance to races 3 and 14 of SCN (24). Cotton was planted on 102-cm rows while corn and soybean were planted on 76-cm rows.

Table 1. Cropping sequences planted over the four-year experimental period at the Research and Education Center at Milan, TN.

\begin{tabular}{|c|c|c|c|c|}
\hline \multirow{2}{*}{$\begin{array}{l}\text { Crop } \\
\text { sequence }\end{array}$} & \multicolumn{4}{|l|}{ Year } \\
\hline & 2002 & 2003 & 2004 & 2005 \\
\hline 1 & Cotton & Cotton & Cotton & Cotton \\
\hline 2 & Corn & Corn & Corn & Corn \\
\hline 3 & Soybean & Soybean & Soybean & Soybean \\
\hline 4 & Soybean & Soybean & Soybean & Cotton \\
\hline 5 & Corn & Soybean & Corn & Soybean \\
\hline 6 & Soybean & Soybean & Soybean & Cotton \\
\hline 7 & Soybean & Cotton & Corn & Soybean \\
\hline 8 & Corn & Corn & Soybean & Cotton \\
\hline 9 & Corn & Cotton & Soybean & Corn \\
\hline 10 & Cotton & Soybean & Cotton & Corn \\
\hline 11 & Cotton & Soybean & Corn & Cotton \\
\hline 12 & Cotton & Corn & Cotton & Soybean \\
\hline 13 & Cotton & Corn & Cotton & Corn \\
\hline
\end{tabular}


Fertilizer was applied as appropriate to each crop according to soil tests and the guidelines published in the Tennessee Agricultural Extension Service Guidelines to Crop Production, and litter was applied at the rate of $66.7 \mathrm{~kg}$ $\mathrm{N} /$ ha, assuming $50 \%$ bioavailability (26). Nutrient content of the poultry litter, vetch, wheat, and winter weeds (fallow) bio-covers were tested by A\&L Analytical Laboratories Inc. (Memphis, TN). To determine nutrient content of vetch, wheat, and winter weeds, a 0.5 -m by $1-\mathrm{m}$ sample of the aboveground living material was taken just prior to spring glyphosate treatment. All bio-cover strips received the equivalent of $66.7 \mathrm{~kg} \mathrm{~N} / \mathrm{ha}\left(\mathrm{NH}_{4} \mathrm{NO}_{3}\right)$ prior to planting. Preplant fertilizer application rates were reduced by the amount of nitrogen supplied by the vetch or other bio-covers, as appropriate. Corn plots received an additional $128.5 \mathrm{~kg} \mathrm{~N} / \mathrm{ha}$ (liquid UAN 30\%) and cotton received $33.35 \mathrm{~kg} \mathrm{~N} / \mathrm{ha}$ (liquid UAN 30\%) as side-dress treatments in late May or early June. Corn, soybean, and cotton plots were planted at the recommended seeding rates of 64,200 seeds/ha, 344,500 seed/ha, and 64,500 seed/ha, respectively (26).

Prior to planting, all emergent weeds were destroyed by either a paraquat (1,1-Dimethyl-4,4-bipyridinium) or glyphosate (N-phosphonomethyl-glycine) application in April. After seedling emergence, one or two applications of glyphosate were applied to the soybean and corn plots in either May or June of each year as needed for weed control. For the cotton plots, additional pesticide use was required and application dates ranged from June through September. Glyphosate and clethodim \{(RS)-2-9[(E)-1-[(E)-3-chloroallyloxyimino] propyl]5-[2-(ethylthio) propyli]-3-hydroxycyclohex-2-en-1-l-one\} were used all four years. Def (S,S,S-Tributyl phosphorotrithioate) and Bidrin (Dimethyl phosphate of 3-Hydroxy-N,N-dimethyl-cis-crotonamide) were used as defoliants, and Pix (1,1-dimethylpiperidinium chloride) was applied to regulate cotton growth.

\section{Sample Collection}

SCN egg population density (EPD) was determined in 2003, 2004, and 2005, the final three years of the four-year cropping sequence. To determine SCN EPD, a composite sample of twelve soil cores $(2.5 \mathrm{~cm}$ in diameter $\times 15 \mathrm{~cm}$ deep) was collected from the within- and between-row sections of each plot. Samples were collected approximately three weeks prior to spring bio-cover burndown during the third week of March. Cysts of SCN were extracted from the soil using a semi-automatic elutriator and eggs liberated and enumerated following the methodology of Niblack et al. (15). SCN egg population densities were rank transformed to correct for non-normality prior to analysis of variance with SAS proc mixed (22). Mean separation was performed using Fisher's LSD $(\alpha<0.05)$ (23). Original means are reported for interpretation.

\section{Effect of Cropping Sequence}

Mean pre-plant SCN EPD over all treatments ranged from $146 \pm 4$ eggs per $100 \mathrm{~cm}^{3}$ of soil in 2004 to $195 \pm 3$ eggs per $100 \mathrm{~cm}^{3}$ in 2005 (Fig 1). SCN infection and development is inhibited in soil with high moisture content (29). The late spring and fall are typically high in precipitation at Milan, TN, but in 2005, June, July, and September were below average in precipitation, with July and September receiving less than $25 \%$ of the historical average precipitation (13). Temperatures in March, April, May, June, and July of 2005 were higher than historical averages, which may have stimulated an early egg hatch and rapid development that year (1). 


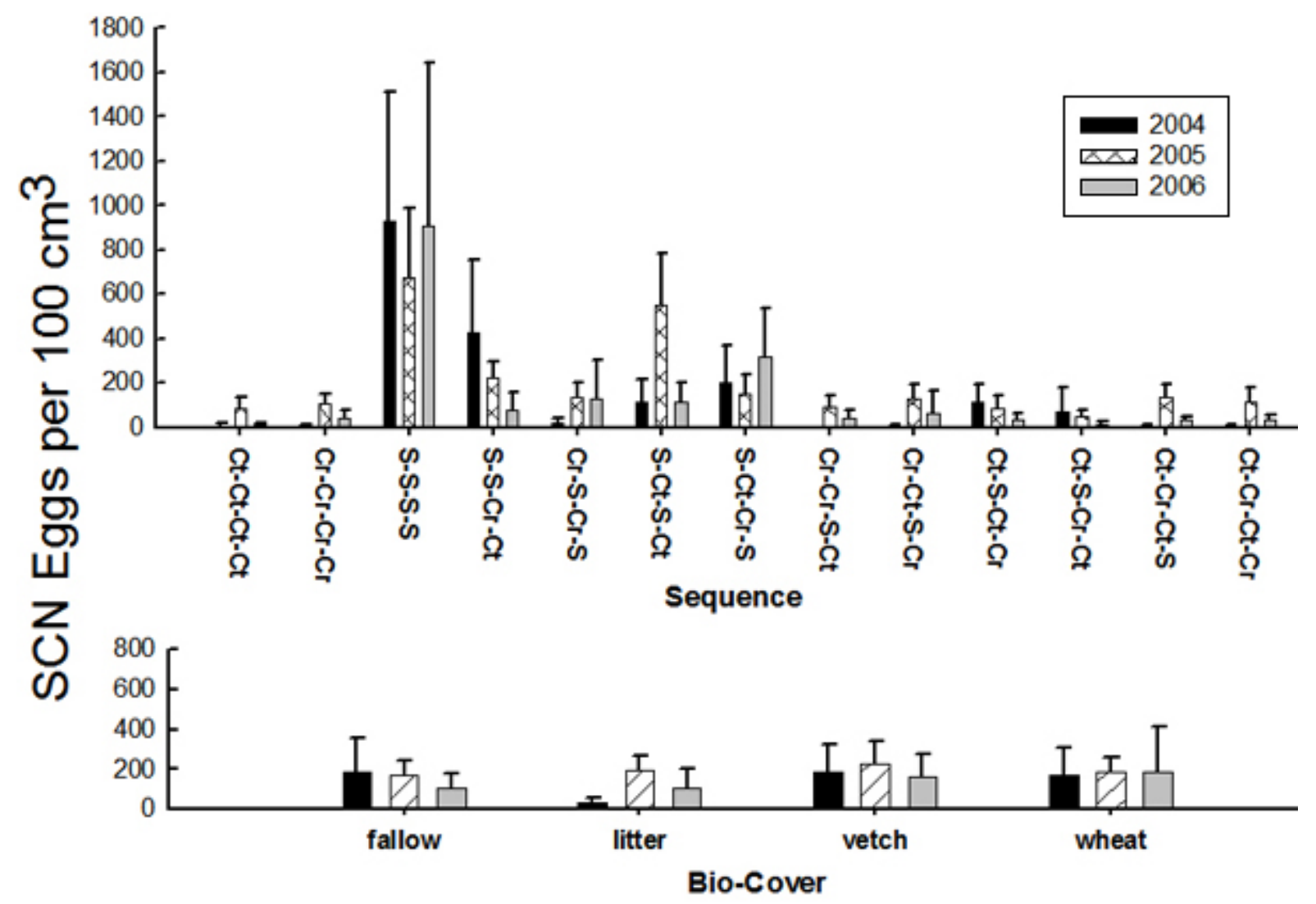

Fig. 1. Changes in soybean cyst nematode (SCN) at the $0-$ to $15-\mathrm{cm}$ depth over time (2004-2006) at the Research \& Education Center at Milan, TN, by crop sequence ( $\mathrm{Ct}=$ cotton, $\mathrm{Cr}=\mathrm{corn}, \mathrm{S}=$ soybean) averaged across bio-covers (top); and by bio-cover averaged across crop sequence (bottom). Error bars denote $95 \%$ confidence interval.

Cropping rotation had a highly significant $(\mathrm{P}<0.01)$ effect on SCN EPD for each of the three years (Table 2). Mean SCN population density was typically higher $(\mathrm{P} \leq \mathrm{0.05})$ in rotations consisting of higher frequencies of soybeans. Additionally, rotations in which the previous year's crop was soybean had higher mean SCN egg densities than those planted in cotton or corn. This result indicates that $\mathrm{SCN}$ was able to infect and reproduce on the soybean variety 'USG 7440nRR,' although this variety is moderately resistant to races 3 and 14 (25). Higher SCN egg densities occurred consistently throughout the 4-year sequence in the continuous soybean treatment. The highest density was $927 \pm 582$ eggs per $100 \mathrm{~cm}^{3}$ of soil after two years of the soybean crop (Fig. 1). SCN egg densities did not differ in subsequent years $\left(672 \pm 313\right.$ eggs per $100 \mathrm{~cm}^{3}$ and $909 \pm 737$ eggs per $100 \mathrm{~cm}^{3}$ of soil in 2005 and 2006, respectively). Assuming an average of 200 eggs per cyst (15), these egg densities are equivalent to approximately 3 to 4 cysts per $100 \mathrm{~cm}^{3}$ of soil, well below the University of Tennessee economic threshold value of 20 cysts per $100 \mathrm{~cm}^{3}$ of soil (14).

SCN EPD dropped after one year of rotation with a non-host crop in all treatments. However, some carryover between years was observed, with rotations that had two years of soybeans in the four-year sequence having higher SCN than rotations with one year of soybean. For example, soybean (S)cotton (Ct)-(S)-(Ct) had higher mean SCN EPD in $2005\left(549\right.$ per $\left.100 \mathrm{~cm}^{3}\right)$ than corn (Cr)-Ct-S-Cr (132 per $\left.100 \mathrm{~cm}^{3}\right)$ and Ct-S-Ct-Cr $\left(81\right.$ per $\left.100 \mathrm{~cm}^{3}\right)$ (Table 2). Chen et al. (4) found similar results where rotation with a soybean cultivar with resistance to $\mathrm{SCN}$ in addition to use of a non-host reduced the population density. These results differ from work reported in Minnesota (11) and Missouri (9) in which one year of non-host crop rotation and winter fallow did not consistently reduce $\mathrm{SCN}$ survival. The discrepancy may be due to different climatic conditions, as regions with warmer winters are less favorable for SCN survival than those with cooler winters (20). 
Table 2. Means and $95 \%$ confidence intervals (CI) for soybean cyst nematode egg population densities (per $100 \mathrm{~cm}^{3}$ of soil) for three years of cropping rotations under no-tillage at the Research and Education Center at Milan, TN.

\begin{tabular}{|c|c|c|c|c|c|c|}
\hline \multirow{3}{*}{$\begin{array}{l}\text { Crop } \\
\text { sequence }\end{array}$} & \multicolumn{6}{|c|}{ Year } \\
\hline & \multicolumn{2}{|c|}{2004} & \multicolumn{2}{|c|}{2005} & \multicolumn{2}{|c|}{2006} \\
\hline & Mean & $95 \% \mathrm{Cl}$ & Mean & $95 \% \mathrm{Cl}$ & Mean & $95 \% \mathrm{Cl}$ \\
\hline $\mathrm{Ct}-\mathrm{Ct}-\mathrm{Ct}-\mathrm{Ct}{ }^{\mathrm{x}}$ & $6 e f y$ & 11 & $84 b c$ & 52 & $12 \mathrm{de}$ & 10 \\
\hline $\mathrm{Cr}-\mathrm{Cr}-\mathrm{Cr}-\mathrm{Cr}$ & $3 e f$ & 6 & $105 b c$ & 43 & 39cde & 35 \\
\hline S-S-S-S & $927 a$ & 582 & $672 a$ & 313 & $909 a$ & 737 \\
\hline S-S-Cr-Ct & 4299ab & 325 & $222 a b$ & 75 & 78 bcde & 78 \\
\hline $\mathrm{Cr}-\mathrm{S}-\mathrm{Cr}-\mathrm{S}$ & 21de & 17 & $138 b c$ & 65 & $132 b c$ & 174 \\
\hline S-Ct-S-Ct & $114 \mathrm{~cd}$ & 100 & $549 a$ & 234 & $114 \mathrm{bcd}$ & 89 \\
\hline S-Ct-Cr-S & $204 b c d$ & 166 & $153 b c$ & 85 & $318 b$ & 217 \\
\hline $\mathrm{Cr}-\mathrm{Cr}-\mathrm{S}-\mathrm{Ct}$ & Of & 0 & $93 \mathrm{~cd}$ & 47 & 42 bcde & 35 \\
\hline $\mathrm{Cr}-\mathrm{Ct}-\mathrm{S}-\mathrm{Cr}$ & $3 e f$ & 6 & $132 b c$ & 62 & $63 \mathrm{cde}$ & 102 \\
\hline $\mathrm{Ct}-\mathrm{S}-\mathrm{Ct}-\mathrm{Cr}$ & $111 a b c$ & 83 & $81 \mathrm{~cd}$ & 61 & 36 cde & 31 \\
\hline $\mathrm{Ct}-\mathrm{S}-\mathrm{Cr}-\mathrm{Ct}$ & 69def & 113 & $51 d$ & 29 & $12 \mathrm{e}$ & 13 \\
\hline $\mathrm{Ct}-\mathrm{Cr}-\mathrm{Ct}-\mathrm{S}$ & $3 e f$ & 6 & $138 b c$ & 58 & 30 bcde & 20 \\
\hline $\mathrm{Ct}-\mathrm{Cr}-\mathrm{Ct}-\mathrm{Cr}$ & $3 e f$ & 6 & $117 \mathrm{~cd}$ & 59 & 33 cde & 26 \\
\hline Average $^{z}$ & 146 & 109 & 195 & 91 & 140 & 121 \\
\hline
\end{tabular}

$\mathrm{x} \mathrm{Ct}=$ cotton, $\mathrm{Cr}=$ corn, $\mathrm{S}=$ soybean. Cropping rotations were started in 2003.

$y$ Values in a column followed by a common letter are not significantly different; Fisher's protected least significant difference at $P \leq 0.05$ was performed on rank transformed data (not shown).

$\mathrm{z}$ Average of all rotations at RECM, $\mathrm{n}=208$; each mean is an average across all bio-covers.

Residual SCN occurred in all plots throughout the experiment, even when soybean was absent in the rotational sequence. For example, continuous cotton $\mathrm{Cr}-\mathrm{Ct}-\mathrm{Cr}-\mathrm{Ct}$ rotation and continuous corn had mean SCN egg population densities greater than zero in all three years. SCN eggs found in rotations without soybean do not appear to be experimental error for five reasons. First, under controlled conditions, $\mathrm{SCN}$ has been shown to survive more than 12 years at soils maintained near field capacity (29). Second, the site was planted in soybean three, six, and nine years prior to initiation of the experiment, and may have developed a well established SCN population. SCN cysts are known to persist in similar environments for over four years. SCN egg dormancy can be dependent on climate conditions, root exudates, and time (28). Third, eggs were found consistently in most bio-covers and treatment plots with entirely nonhost cropping rotations each year. Fourth, those plots exhibiting SCN infestation in any single year continued to have elevated egg densities throughout the course of the experiment. Finally, there may have been some reproduction on weeds that grew on the plots over the winter. Although no reproduction was seen on winter weeds by Donald et al. (6), given favorable weather conditions, SCN can reproduce on chickweed (Stellaria media) and henbit (Lamium amplexicaule) (21), which grew on soybean sites during the non-growing period. Although soybean planting frequency is typically responsible for elevated SCN counts, these results indicate that reproduction in the bio-cover may play a role in $\mathrm{SCN}$ population density.

\section{Role of Bio-Covers}

Although variability obscured any possible treatment significance, there were some trends among the mean SCN population densities under winter bio- 
covers (Fig. 2). Fallow, poultry litter, and wheat SCN population densities were lower than the average SCN density two out of the three years (Table 3). This observation in the fallow bio-cover is in agreement with research performed by Donald et al. (6) who found no SCN reproduction on weeds in winter fallowed soybean fields in southwestern Tennessee.
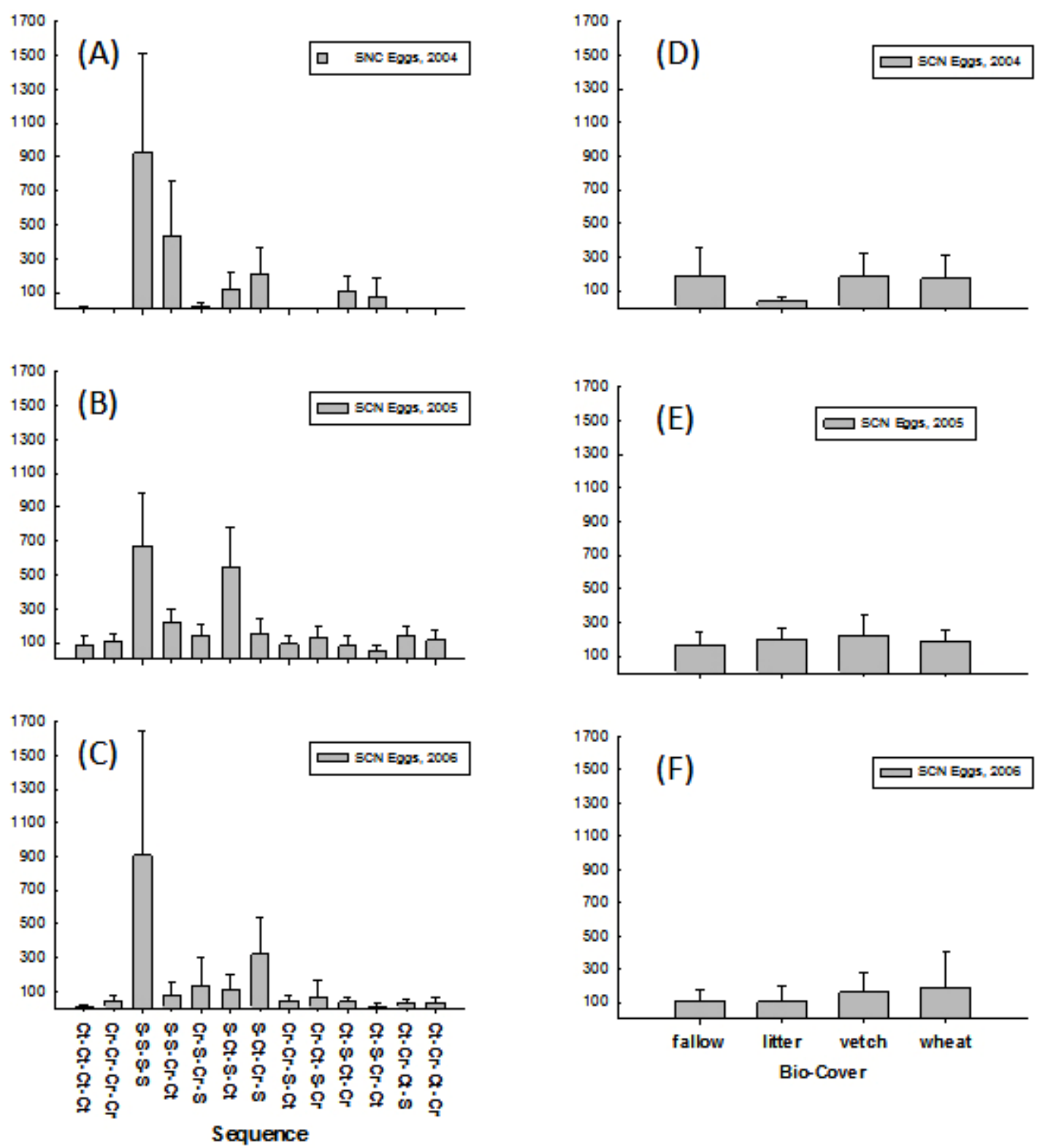

Fig. 2. Changes in soybean cyst nematode (SCN) 0- to 15-cm over time (2004-2006) at the Research \& Education Center at Milan, TN, by crop sequence ( $\mathrm{Ct}=$ cotton, $\mathrm{Cr}=$ corn, $\mathrm{S}=$ soybean) averaged across bio-covers in 2004 (A), 2005 (B), and 2006 (C) and by bio-cover averaged across crop sequence in 2004 (D), 2005 (E), and 2006 (F). Error bars denote 95\% confidence interval ( $\pm 2 *$ std. error). 
Table 3. Means and 95\% confidence intervals (CI) for soybean cyst nematode egg population densities (per $100 \mathrm{~cm}^{3}$ of soil) for three years of bio-covers under notillage at the Research and Education Center at Milan, TN.

\begin{tabular}{|c|c|c|c|c|c|c|}
\hline \multirow{3}{*}{$\begin{array}{l}\text { Bio- } \\
\text { cover }\end{array}$} & \multicolumn{6}{|c|}{ Year } \\
\hline & \multicolumn{2}{|c|}{2004} & \multicolumn{2}{|c|}{2005} & \multicolumn{2}{|c|}{2006} \\
\hline & Mean & $95 \% \mathrm{Cl}$ & Mean & $95 \% \mathrm{CI}$ & Mean & $95 \% \mathrm{Cl}$ \\
\hline Fallow & $188 a^{x}$ & 167 & $169 a$ & 74 & $105 a$ & 74 \\
\hline Litter & $36 a$ & 24 & $198 a$ & 66 & $103 a$ & 99 \\
\hline Vetch & $184 a$ & 137 & $224 a$ & 115 & $162 a$ & 118 \\
\hline Wheat & $175 a$ & 135 & $189 a$ & 68 & $189 a$ & 220 \\
\hline Averagey & 146 & 116 & 195 & 81 & 140 & 128 \\
\hline
\end{tabular}

${ }^{x}$ Values in a column followed by a common letter are not significantly different; Fisher's protected least significant difference at $P \leq 0.05$ was performed on rank transformed data (not shown).

y Average of all rotations at RECM, $\mathrm{n}=208$; each mean is an average across all bio-covers of that crop rotation.

Though others have found that wheat residue can have a suppressive effect on SCN (7), no significant wheat bio-cover effect was observed in this study. Across all crop rotations, SCN EPD under poultry litter was lowest of all biocovers in two of the three years, ranging from $36 \pm 2$ eggs per $100 \mathrm{~cm}^{3}$ to $103 \pm$ 7 eggs per $100 \mathrm{~cm}^{3}$ in 2004 and 2006, respectively (Table 3). Others have found that poultry litter can promote the growth of bacteria and fungi (19), and may increase the population of nematophagous fungi, such as Fusarium solani, F. oxysporum, Paecilomyces lilacinus, and Verticillium chlamydosporium, which parasitize SCN (3). This parasitism may explain the slightly lower mean SCN egg densities observed in this study under poultry litter.

Vetch supported higher mean SCN densities in all three years. The highest SCN EPD across all bio-covers and years, $224 \pm 8$ eggs per $100 \mathrm{~cm}^{3}$, was seen under vetch in 2004, supporting the findings of Riggs (21), who found that hairy vetch can serve as a host to SCN under proper conditions. During the historically warm winter of 2004-2005, SCN egg densities were highest in continuous soybean with vetch bio-cover $\left(1068 \pm 108\right.$ eggs per $\left.100 \mathrm{~cm}^{3}\right)$.

\section{Conclusions}

In spring 2006, SCN eggs were found in plots that had not been planted with soybean for seven years indicating that even with a low level of SCN, the nematode cannot be eliminated from infested soil in this length of time. SCN was able to establish and maintain an infective population on the cultivar 'USG 7440nRR,' which is rated as moderately resistant to SCN races 3 and 14. Likely due to this resistance, EPD remained well below the economic threshold throughout the experiment. Rotating SCN resistant soybean with non-host agronomic crops can reduce SCN EPD, with as little as one year being enough to reduce SCN density dramatically. These effects were cumulative, with EPD declining with decreasing frequency of soybean in four year crop rotations. Mean EPD was generally lowest under the poultry litter bio-cover and highest under hairy vetch, with wheat and fallow being intermediate.

\section{Acknowledgements}

The authors would like to thank The University of Tennessee Agricultural Experiment Station for funding this work and The University of Tennessee Research and Education Center at Milan for providing the study site and field operations. We also thank Dr. Pat Donald and her staff at the USDA-ARS Crop Genetics and Production Research Unit for assistance with nematode sampling and count data. We are grateful to Heather Hart, Jennifer E. Noe, and Rachel Grindle for their technical assistance. 


\section{Disclaimer}

Mention of trade names or commercial products is for the purpose of providing information and does not imply endorsement.

\section{Literature Cited}

1. Alston, D. G., and Schmitt, D. P. 1987. Development of Heterodera glycines life stages as influenced by temperature. J. Nematol. 20:366-372.

2. Baird, S. M., and Bernard, E. C. 1984. Nematode population and community dynamics in soybean-wheat cropping and tillage regimes. J. Nematol. 16:379-386.

3. Bernard, E. C., Self, L. H., and Tyler, D. D. 1996. Fungal parasitism of soybean cyst nematode, Heterodera glycines (Nemata:Heteroderidae), in differing cropping tillage regimes. Applied Soil Ecol. 5:57-70.

4. Chen, S. 2007. Tillage and crop sequence effects on Heterodera glycines and soybean yields. Agron. J. 99:797-807.

5. Creech, J. E., Johnson, W. G., Faghihi, J., Ferris, V. R., and Westphal, A. 2005. First report of soybean cyst nematode reproduction on purple deadnettle under field conditions. Online. Crop Management doi:10.1094/CM-2005-0715-01-BR.

6. Donald, P. A., Hayes, R., and Walker, E. 2007. Potential for soybean cyst nematode reproduction on winter weeds and cover crops in Tennessee. Online. Plant Health Progress doi:10.1094/PHP-2007-0226-01-RS.

7. Hershman, D. E., and Bachi, P. R. 1995. Effect of wheat residue and tillage on Heterodera glycines and yield of doublecrop soybean in Kentucky. Plant Dis. 79:631-633.

8. Howard, D. H., Chanbers, A. Y., and Lessman, G. M. 1998. Rotation and fertilization effects on corn and soybean yields and soybean cyst nematode populations in a no-tillage system. Agron. J. 90:518-522.

9. Jackson, T. A., Smith, G. S., and Niblack, T. L. 2005. Heterodera glycines infectivity and egg viability following nonhost crops and during overwintering. J. Nematol. 37:259-264.

10. Koenning, S. R., Schmitt, D. P., and Barker, K. R. 1993. Effects of cropping systems on populations-density of Heterodera glycines and soybean yield. Plant Dis. 77:780-786.

11. Miller, D. R., Chen, S. Y., Porter, P. M., Johnson, G. A., Wyse, D. L., Stetina, S. R., Klossner, L. D., and Nelson, G. A. 2006. Rotation crop evaluation for management of the soybean cyst nematode in Minnesota. Agron. J. 98:569-578.

12. Moore, W. F., Fox, J. A., and Patel, M. V. 1991. Soybean cyst nematode. Coop. Ext. Serv. Publ. 1293. Mississippi State Univ., Mississippi State, MO.

13. National Climate Data Center. 2006. Online. NOAA Satellite and Information Service, NESDIS, US Department of Commerce, Washington, DC.

14. Newman, M. A. 2003. Disease management in soybeans using cultural practices and genetic resistance. Online. Pages 14-15 in: PB1608 Soybean Production in Tennessee. Agric. Ext. Service, The University of Tennessee, Knoxville, TN.

15. Niblack, T. L. 2005. Soybean cyst nematode management reconsidered. Plant Dis. 89:1020-1026.

16. Noel, G. R., and Edwards, D. I. 1996. Population development on Heterodera glycines and soybean-maize rotations following introduction into a noninfested field. J. Nematol. 28:335-342.

17. Noel, G. R., and Wax, L. M. 2003. Population dynamics of Heterodera glycines in conventional tillage soybean/corn cropping systems. J Nematol. 35:104-109.

18. Porter, P. M., Chen, S. Y., Reese, C. D., and Klossner, L. D. 2002. Population response of soybean cyst nematode to long term corn-soybean cropping sequences in Minnesota. Agron. J. 93:619-626.

19. Riegel, C., and Noe, J. P. 2000. Chicken litter soil amendment effect on soilborne microbes and Meloidogyne incognita on cotton. Plant Dis. 84:1275-1281.

20. Riggs, R. D. 2004. History and distribution. Pages 9-40 in: Biology and Management of the Soybean Cyst Nematode 2nd Edn. D. P. Schmitt, J. A. Wrather, and R. D. Riggs, eds. Schmitt \& Assoc. of Marceline, Marceline, MO.

21. Riggs, R. D., Niblack, T. L., Kinloch, R. A., MacGuidwin, A. E., Mauromoustaskos, A., and Rakes, L. 2001. Overwinter populations dynamics of Heterodera glycines. J. Nematol. 33:219-226.

22. SAS Institute. 2008. SAS Version 9.2. SAS Institute Inc., Cary, NC.

23. Saxton, A. M. 1998. A macro for converting mean separation output to letter groupings in Proc Mixed. Pages 1243-1246 in: Proc. 23rd SAS Users Group Intl., SAS Institute Inc., Cary, NC. 
24. Stromberg, E. L. 2011. Diseases and Nematodes: Soybeans. Online. Pest Management Guide: Field Crops, 2011. Virginia Coop. Ext., Virginia Tech, and Virginia State Univ., Blacksburg, VA.

25. Tyler, D. D., Chambers, A. Y., and Young, L. D. 1987. No-tillage effects on population dynamics of soybean cyst nematode. Agron. J. 79:799-802.

26. UT Extension Service. 2003. Guidelines for developing and implementing a poultry nutrient management plan. Online. Agric. Ext. Serv. Publ. PB1644. Inst. of Agric., Univ. of Tennessee, Knoxville, TN.

27. Venkatesh, R., Harrison, S. K., and Riedel, R. M. 2000. Weed hosts of soybean cyst nematode (Heterodera glycines) in Ohio. Weed Technol. 14:156-16o.

28. Yen, J. H., Niblack, T. L., and Wiebold, W. J. 1995. Dormancy of Heterodera glycines in Missouri. J. Nematol. 27:153-163.

29. Young, L. D., and Heatherly, L. G. 1988. Soybean cyst nematode effect on soybean grown at controlled soil water potentials. Crop Sci. 28:543-545. 